\title{
On the Determinants of Dividends' Information Content
}

\author{
Hatem Ben Said ${ }^{1}$ \\ ${ }^{1}$ Higher Institute of Gabes, Gabes, Tunisia \\ Correspondence: Hatem Ben Said, Higher Institute of Gabes, Gabes 6002, Tunisia. E-mail: \\ bensaidhtm@gmail.com
}

Received: June 16, 2012 Accepted: July 10, 2012 Online Published: August 14, 2012

doi:10.5539/jms.v2n2p276 URL: http://dx.doi.org/10.5539/jms.v2n2p276

\begin{abstract}
This paper examines the determinants of dividends' information content. We put an emphasis on the role of ownership structure in explaining the impact of dividends on shareholders' wealth. To this end, our study examined a sample of 136 French firms during the year 2007 to empirically validate our model. The empirical results show a negative reaction of stock prices to dividend announcement. This finding is consistent with the hypothesis of deterioration of growth opportunities. However, we have concluded that firms' characteristics significantly affect dividends' information content.
\end{abstract}

Keywords: dividends, shareholders' wealth, dividends' information content, cumulative abnormal returns, ownership structure

\section{Introduction}

Empirical studies on the impact of dividends on shareholder wealth in the context of signaling and agency theories are mixed. In a context of perfect markets, Modigliani and Miller (1961) point to the irrelevance of dividend policy on shareholder wealth. However, Gordon (1959) argues that the stock price increases along with dividend yield ratio. Similarly, under the agency theory, Easterbrook (1984), Jensen (1986) and Frankfurter and Wood (2002) emphasize that the distribution of dividends reduces agency costs. Also as part of signaling theory, Bhattachraya (1979), Asquith and Mullins (1986), and John Williams (1985) and Miller and Rock (1985) argue that the distribution of dividends transmits signals to outside investors and affects firm's positive value. However, other work, including Litzenberger and Ramaswamy, (1979) conclude with a negative relationship between dividends and shareholder wealth.

However, under agency and signaling theories, Alpa and Dhanani (2005) argue that the industry affects dividends' information content. Baker, Powell (1999) and Baker and al (2002) highlight the fact that a firm's specific factors may affect the message transmitted by the distribution of dividends. Philip and al (2008) examine the effect of business sectors in classifying their sample into three sectors: natural resources sector, finance sector and other activities.

La porta and al (2000), Ball Kothari and Robin (2000) highlight the role of ownership structure in explaining the information content of dividends. Indeed, in the case of French, minority shareholders are poorly protected by law, which favors the consumption of private benefits by controlling shareholders and managers. This behavior reduces the amount of distributed dividends and negatively affects, consequently, shareholder wealth. Likewise, Lightner and al (2008) and Samuel and Edward (2011) analyze the role of institutional shareholders, such as internal governance mechanism, in the relationship between dividends and shareholder wealth. Defond and al (2004), La Porta and al., 1999, Brown and Higgins (2005) Demirguc-Kunt and Maksimovic (1998) point to the effect of ownership structure between countries by building indices that measure ownership concentration, law and managerial ownership.

The aim of this paper is to identify the determinants of dividends' information content (in particular ownership structure). We will review in the second section empirical works on the dividends' information content. Data and empirical methodology are presented in section three. In section four, we report and discuss our empirical results. We shed light, also, on sensitivity tests of our results. In section five, we will present our conclusions.

\section{Literature Review}

Dividends' information content is a subject at the heart of debates on corporate finance. In the context of the approach of neutrality, model MOMI (1961), the great proponent of dividends neutral approach, study the 
impact of dividends on the firm value in a context of a perfect market condition and conclude that, given a fixed firm's investment schedule, dividend policy does not affect the current prices of these shares or the total returns of the shareholders. Rubinstein (1976) studied the neutrality of dividend policy in a perfect market and in an inter-temporal horizon $(t=0,1,2)$ and concludes with neutrality of dividend policy. Inspired by the results of MOMI (1961), Kamstra (2000) made clear his position in favor of the neutral approach by deriving a formula for evaluating a dividends-distributing firm. Thus, the arguments emphasized by supporters of the neutrality approach contradict the relevance of dividends approach crowned by Gordon and Shapiro's paper (1956), which is a continuation of research conducted as part of the relevance of dividends approach. The approach aims at explaining dividends' information content whereas the objective of the firm is to maximize insider's wealth and set the stock price as equal to the sum of dividends discounted at a required return. DeAngelo DeAngelo's article (2006), which was seen as a turning point in the study of dividends' information content. DeAngelo DeAngelo (2006) argues that the assumption of neutrality of dividends on firm value of MOMI (1961) is erroneous and is an immediate result of their initial assumption which states the total distribution of "Cash Flow". Easterbrook (1984) highlights that dividend policy corrects the overinvestment problem because dividends distribution increases the likelihood that the firm was financed by the financial market, and be therefore subject to external control. This process reduces the agency costs of equity market. On this, Handjinicolaou and Kalay (1984) report that current dividends are positively affected by the change in dividends.

Similar to Healy and Palepu (1988), Nissim and Ziv (2001), Michaely and al (1997), Dyl and Weigand (1998), Grullon and al (2002), Koch and Sun (2004) Neil and Robert (2009) attempted to explain whether the message conveyed by the dividend distribution based on individual characteristics of firms from the perspective of agency and signaling theory and clientele effects. The authors calculated the cumulative abnormal returns using Fama and French's three-factor model. Using a sample of 594 firms listed on New York Stock Exchange, "NYSE" and American Stock Exchange, "AMEX" distributing dividends for at least two successive years for a 37-year period from 1964 to 2000, the authors empirically pointed to a positive relationship between dividends and stock prices for firms with ratios weak "Market to Book" ratios. The authors also report an inverse relationship between cumulative abnormal returns and systematic risk for firms with low growth opportunities and a positive relationship between stock prices and profitability for firms with high growth opportunities.

Following the work of Frankfurter and Wood (2002), Konstantinos and al (2011) analyze dividend policy under the assumption of information asymmetry. Using a sample of 991 dividend announcements of firms listed on London the Stock Exchange and part of the index "FTSE350" for a period of 5 years from 2006 to 2010, the authors pointed to positive cumulative abnormal returns and statistically significant around announcement date of dividends and net results. In a second step, the authors tried to identify the determinants of the information content of dividends. Using the Ordinary Least Square method, the authors find a positive and statistically significant relationship between managerial ownership and dividends' information content. Moreover, the empirical results show a significant effect between firm-specific factors and dividends' information content.

Consistent with the work of Boehem and Sorescu (2002) and Brav and al (2005), Janice and al (2011) studied market reaction of firms making a takeover bid. Using a sample of 743 Australian firms for a period of 13 years from 1992 to 2004 (332 firms that distribute dividends and 431 firms that do not distribute dividends) and using the method of event study, the authors find a positive and statistically significant stock price reaction after 5 years from dividends' announcement date. However, in order to test the validity of signaling and free cash flows theories, Janice and al (2011) calculate the excess return that equal to the difference between the ratios of return on assets, "ROA" and return on equity, "ROE". The empirical results indicate a negative excess return on equity and statistically significant for the fourth and fifth years after distribution of dividends. Furthermore the authors conclude that firm performance is best explained in the context of signaling theory rather than the theory of free cash flow.

\section{Data and Methodology}

\subsection{Sample Selection}

Our article examines the role of ownership structure in explaining dividends' information content in the French context. Indeed, Gelb (2000) and Shleifer and Vishny (1997) point out that unlike the United States and England known for dispersed shareholding, a large fraction of the French companies' shares is in the hands of few shareholders (concentrated ownership). Our sample contains data on 136 firms for the year 2007 break down as follows between sectors; 10 oil companies, 64 industrial firms, 14 transportation firms, 18 trade firms, 30 service firms. 
Studying the determinants of financial policy requires the use of different sources of information. The "MERGENTONLINE", "DATASTREAM", "FACTIVA", "REUTERS" and "IMF" databases are our primary sources of information. Occasionally, we use the data "MERGENTONLINE" to collect accounting data and financial information from companies' financial statements. Firms' market capitalization is found through accessing "DATASTREAM" database. Stock prices are obtained from databases "FACTIVA" and "Reuters". Regarding the macroeconomic factors used to calculate the market value of debt (long-term and short-term interest rates, consumer prices index), they are obtained from "IMF" database.

\subsection{The Models}

\subsubsection{Event Study Method}

Studying the effect of dividends on stock prices (Fama \& French, 1988), is conducted through an event study test as suggested by Thompson (1985) and Margaret Johnston (2007) and Cheng and al (2011). The test is used to measure the impact of events on firms' stock prices (Binder, 1998). The event study method is divided into four phases described as follows. The first step is to identify precisely the event of the distribution of dividends. Once we identified the event, it is useful to determine the announcement date, which in our case corresponds to the general meeting date. During the third step, we defined the event and estimation period. The estimation period starts from the day "-20" to days "- 11 " (with the announcement date as date $\mathrm{t}=0$ ), which is used to estimate the market model's parameters. The event period, which runs from the day "-10" to days "10" is used to calculate abnormal returns. The last step is to use the "CAPM" to calculate stock returns;

\subsubsection{Cross-sectional Analysis}

In this section, using the explanatory variables highlighted by the work of Wansley and al (1991), Impson (1997), Lee and Yan (2003), Fuller (2003), McClusky and al (2006), and the methodology of Cheng and Wallace Leung (2011) and Dasilas and Leventis (2011) who exploit the determinants of cumulative abnormal returns, we test the cross-sectional regressions to examine the relationship between the cumulative abnormal returns and the independent variables following the methodology advocated by Zhenhu Jin (2000).

\section{$\mathrm{CAR}=\mathrm{f}(\mathrm{SIZE} ;$ EARNVOL; INST; BOARD; H; Q; DIV; PRECAR; DEBT; CASH)}

With "CAR", cumulative abnormal returns, "SIZE", firm size, "EARNVOL", volatility of earnings per share "INST", participation of institutional shareholders, "BOARD", participation of leaders, "H", Herfindhal index; "Q", Tobin's Q, "PRECAR", market timing, "DEBT", debt ratio, "CASH", liquidity ratio.

\subsection{Variables Choice and Hypotheses}

In accordance with empirical works (Agrawal \& Jayaraman, 1994; Amidu \& Abor, 2006, Chen \& Steiner, 1999; Dickens \& al., 2003, Holder \& al., 1998; Omran \& Pointon, 2004; Ooi, 2001; Wang \& al., 1993; Zeng, 2003), this section attempts to identify determine the dividends' information content for the entire sample and for both subgroups.

\subsubsection{Variables Choices}

\section{The dependant variable}

Cumulative Abnormal Returns (market response): We contribute to existing research through an empirical study of the reaction of shareholders following the dividends announcement by calculating cumulative abnormal returns "CAR" using the market factor model and the event study method as described by Brown and Warner (1985). We estimate the model's parameters on a 10 day-window (from day - 20 to day - 11) using the market return calculated using the market index "SBF 250." following the methodology recommended by Asquith and Mulins (1986) Oliver Zhen (2007) and Shania and Yuce (2011), we measure the market reaction following the distribution of dividends by the cumulative abnormal returns for "1", "2", "6" and "8" days after the dividend announcement date. This variable is used again as the dependent variable to test whether the characteristics affect the relationship between dividends distribution and shareholder wealth. Using alternatively, CAR1, CAR2, CAR6 and CAR8, we divide our total sample into two subgroups with positive and negative cumulative abnormal returns.

\section{The independent variables}

Cumulative Abnormal Returns (market timing): The cumulative abnormal returns from day " $\mathrm{t}=-10$ " to day $" t=-2 "$ are used to control market timing in the event of distribution of dividends. If, on this window observed abnormal returns are negative, "PRECAR" must be positive, and inversely related to "CAR". 
Firm size: Similarly to Viswanath and al (2002), we define firm size as the natural logarithm of market capitalization calculated at two days before the dividend announcement date. Empirical work of Mougoue and Rao (2003) and Alpa and Dhanni (2005) document a reverse relationship between firm size and dividend payout. Indeed, in a context of asymmetric information, low size firms trying to distribute more dividends in order to transmit a signal to outside investors on their financial health. The sign of coefficient for this variable is expected to be negative.

Earnings volatility: Differently to Rubin and Smith (2009) who approximate the volatility by the standard deviation of stock returns, we use the standard deviation of earnings per share calculated on 11 years. In a context of asymmetric information, Bhattacharay (1979) argue that dividend policy is a signaling mechanism for firms. In doing so, firms with net income more volatile distribute more dividends in order to send a good signal to outside investors. The coefficient of this variable is expected to be positive.

Institutional ownership: Slovin and Sushka (1993), Knopf and Teall (1996) and Ang and al (2000), argue that the ownership structure could also affect the message conveyed by dividends especially as French companies are recognized as having concentrated ownership. Agency and signaling theory predicts a negative coefficient for institutional ownership structure.

Managerial ownership: Besides the nature of diluted or concentrated capital, the identity of shareholders (whether manager or outside investors) also seems to influence dividends' information content (Faccio \& Lang, 2002). Managerial ownership is approximated as the percentage of shares held by members of the board. High levels of managerial ownership reduce the information asymmetry between insiders and outsiders (Lin \& al, 2007). The expected sign of this coefficient is positive.

Consistent with the works of Stulz (1988), Jarell and Poulsen (1988) and Morck and al (1988), Mc Connel and Servaes (1990) and Hermalin and Weisbach (1991), Hiraki and al (2003) and Chen and al (2003), the impact of managerial ownership on wealth shareholders is nonlinear. Similarly, Rozeff (1982) asserts the existence of a reverse relationship between dividends and managerial ownership. However, for high levels of managerial ownership, Barney and Schooley (1994) emphasize the existence of an entrenchment effect. To take into account this effect, we introduce a "DUMMY" variable which equals 1 if managerial ownership is more than $15 \%$, otherwise it is zero. McWilliams (1990) justifies this threshold value by suggesting that managers begin to deviate from firm-value-maximizing behavior if the equity shares of managers are above $10 \%$ and below $20 \%$.

Concentration of ownership: Herfindahl index: The French market firms are characterized by concentrated ownership structure, which promotes the study of the effect of capital concentration on dividend policy (Jacelly \& Maximiliano, 2010, Demsetz \& Lehn, 1985). The Herfindahl index, "H", provides information on the concentration of ownership. The index "Herfindahl" is computed as the sum of the squares of the shares held by each individual shareholder. Under the agency theory, a high value of the "Herfindahl" index means that the shareholders of the firm is concentrated, which will decrease the agency costs and information asymmetries between managers and shareholders (Shleifer \& Vishny, 1986). The coefficient on this variable is expected to be positive (Kimie and Pascal, 2011).

Tobin's Q ratio: According to Lang and Litzenberger (1989) and Impson (1997) and McConnell and Servaes (1990) Tobin's Q ratio is a measure of a firm's over-investment policy. A high value of this ratio is interpreted by the market as a good signal to outside investors (Easterbrook, 1984). In contrast, Zhenhu Jin (2000) asserts that it is the dividend which sends a signal of deterioration in growth opportunities. The expected sign is negative. We use the ratio "Q" Tobin as defined by Miguel and Pindado (2001), as the sum of market capitalization and market value of debt divided by the replacement cost of assets.

Dividend yield: Dividend yield is measured as the ratio of dividend per share divided by share price two days before the dividend announcement date (Faccio, Lang \& Young, 2001; Chen, 2009; Liang, Moreau \& Jung, 2011). The effect of dividend yield on stock prices is ambiguous. Agency and signaling theories imply that the dividend yield positively affects stock prices (Belden, Todd \& Knapp, 2005, and Ariff Finn, 1986; Lee Bong, 1995). On the other side, the hypothesis of deteriorating growth opportunities and other empirical work (Easstons \& Sinclair, 1989; Hamid, 2003) imply a negative relationship.

Leverage ratio: Under the agency theory, Borokhovich (2005) highlights that a high debt ratio decreases the surplus funds in the hands of managers by forcing them to pay financial expenses. Similarly, in the context of signaling theory, Leland and Pyle (1977) and Ross (1977) estimate that the value of the firm increases with the debt ratio. Assuming that debt and dividends are two signaling mechanisms substitutable (Ross, 1977; Rozeff, 1982), the coefficient of this variable is expected to be positive. 
Liquidity Ratio: Most previous empirical studies investigating the impact of liquidity on dividends' information content (Darling and Paul, 1957), Lie (2000) and Borokhovich (2005), Beiner and Gibson, 1999, Megginson, 1990, Zingales 1995). In fact, for firms with high liquidity amounts, shareholders force managers to distribute more dividends to avoid investment in projects with negative net present value. The coefficient of this variable is expected to be positive.

Sectors: Taking into account the effects of activity sectors (Baker, Farrelly \& Edelman 1985; Lintner, 1956, Baker, 1988) this variable is needed when seeking a comparative view of corporate financial policy. Firms' classification according to their sectors is carried out using "SIC" codes available in the "MERGENTONLINE" database. The inclusion of this variable is essential while considering five activity sectors; oil sector, industrial sector, transport sector, trade sector and service sector, defined by the following binary variables, which are equal to 1 if the firm belongs to an industry and zero otherwise.

Table 1. Measures of variables and predicted signs

\begin{tabular}{|c|c|c|c|}
\hline Variable & Name & measure & Predicted sign \\
\hline $\begin{array}{l}\text { Cumulatifs abnormal } \\
\text { return }\end{array}$ & CAR & $C A R_{t}=\sum_{t-1}^{0} A R_{k t}$ avec $\mathrm{t}=1,2,6$ et 8 & Dependant variable \\
\hline Market anticipation & PRECAR & $\operatorname{PRECAR}_{t}=\sum_{t=-10}^{p} A R_{k t}$ pour $\mathrm{p}=23,5$ et 10 & - \\
\hline Firms size & SIZE & $S I Z E=L N\left(N \times P_{t-2}\right)$ & - \\
\hline volatility & EARNVOL & $E A R N V O L=\sigma(B P A)$ & + \\
\hline $\begin{array}{l}\text { Institutional } \\
\text { ownership }\end{array}$ & INST & $\operatorname{INST}_{i}=\sum_{i=1}^{n} P_{i}$ & - \\
\hline $\begin{array}{l}\text { Managerial } \\
\text { ownership }\end{array}$ & BOARD & $\operatorname{BOARD}_{i}=\sum_{n=1}^{N} P_{n}$ & + \\
\hline Dummy variable & DUMMY & $D U M M Y=\left\{\begin{array}{cc}1 & \operatorname{siBOARD_{i}}>0,15 \\
0 & \text { sinon }\end{array}\right.$ & \\
\hline Herfindhal index & $\mathrm{H}$ & $H=\sum_{i=1}^{n} P_{i}^{2}$ & + \\
\hline Tobin's Q & Q & $Q_{i t}=\frac{M V E_{i t}+M V D_{i t}}{K_{i t}}$ & - \\
\hline Dividend yield & DIV & $D I V=\frac{D P A}{P_{t-2}}$ & - \\
\hline Leverage ratio & DEBT & $D E B T=\frac{D L T+D C T}{\text { total assets }}$ & + \\
\hline Liquidité ratio & $\mathrm{CASH}$ & CASH $=\frac{\text { liquidity }}{\text { total assets }}$ & + \\
\hline
\end{tabular}

AR, abnormal returns; N, number of shares; P, stocks prices; MVE, market value equity; MVD, market value of debt; $\mathbf{K}$, replacement cost of assets; DPA, dividend per share; DLT, long term debt; DCT, short term debt

\subsubsection{Hypotheses to Be Tested}

Bhattacharay (1979), Kalay (1980), Miller and Rock (1985) and Ambarish and al (1987) Dewenter and Warther (1998), Garrett, Priestley (2000), Brav and al (2005) Bessler and al (2009) and Janice and al (2011) assumed that dividend policy acts as a signaling mechanism to manage the information asymmetry between managers and shareholders. They argue that managers distribute dividends to transmit signals to outside investors and distinguish themselves from other unprofitable companies (David \& Osobov, 2008). According to the theory of signaling by the distribution of dividends, which serves as a foundation for our study, the first hypothesis is formulated, then, as follows: 
Signaling hypothesis (1a): Dividend policy reduces information asymmetry between managers and shareholders and, therefore, increases shareholder wealth.

In what follows, we will try to reformulate this hypothesis in the context of agency theory. The dividend is used to reduce agency problems because managers can deviate from shareholder wealth-maximizing behavior (Rozeff, 1982; Easterbrook, 1984). First, by distributing Free Cash Flow to shareholders, dividends reduce the likelihood that managers invest in suboptimal projects (La Porta \& al, 2000). Second, dividends distribution requires firms to obtain financing from external financial markets, and be subject thereafter, to the external control (Jensen, 1986). So, the hypothesis under agency theory assumes that dividend policy reduces agency costs and increases shareholder wealth.

Agency hypothesis (1b): Dividend policy reduces the agency problems between managers and shareholder and improves, therefore, shareholder wealth.

However, Zhenhu Jin (2000) highlights that the distribution of dividends implies a lack of growth opportunities resulting in a negative market reaction. So our third hypothesis can be formulated as follows:

Hypothesis of growth opportunities (1c): Dividend policy implies a deterioration of growth opportunities and reduces, therefore, shareholder wealth.

The interest is now focused to develop the research hypotheses concerning the impact of factors explaining dividends' information. Zhenhu Jin (2000) points out that share prices of 30\% to $40 \%$ of firms that distribute dividends negatively react. Similarly, Fama and French (2001) highlight that characteristic of public firms affects the amount of dividends distributed. The problem here is to test the existence of a statistically significant relationship between the informational effect of dividends and a firm's specific factors. In doing so, we develop the following two assumptions:

Hypothesis 2: Cumulative abnormal returns are linked to a firm's specific factors.

Hypothesis 3: The negative market reaction is not related to a firm's specific factors.

\section{Empirical Results}

\subsection{Descriptive Statistics}

Table 2 reports the dispersion of the announcements dates of dividend in our sample.

Table 2. Dispersion of announcement date of dividends

\begin{tabular}{lll}
\hline Trimestre & Nombre d'annonces des dividendes & pourcentage \\
\hline Premier trimestre & 1 & $0.73 \%$ \\
Deuxième trimestre & 121 & $88.97 \%$ \\
Troisième trimestre & 8 & $5.88 \%$ \\
Quatrième trimestre & 6 & $4.41 \%$ \\
& 136 & $100 \%$ \\
\hline
\end{tabular}

From this table, it appears that $88.97 \%$ of the firms in our sample declares dividend in the second quarter. The descriptive statistics for the entire sample and both sub samples are represented in table 3 .

Table 3. Descriptive statistics

\begin{tabular}{lccccccccc}
\hline & & CAR1 & \multicolumn{2}{c}{ CAR2 } & \multicolumn{2}{c}{ CAR6 } & \multicolumn{2}{c}{ CAR8 } \\
\hline Variables & ENIER & P1 & N1 & P2 & N2 & P6 & N6 & P8 & N8 \\
CAR1 & -0.00285 & 0.0171 & $-0.0250^{* *}$ & 0.0170 & -0.0160 & 0.00998 & -0.0143 & 0.00827 & -0.0116 \\
CAR2 & -0.00595 & 0.0142 & -0.0234 & 0.0218 & -0.0242 & 0.0127 & -0.0225 & 0.0111 & -0.0194 \\
CAR6 & -0.00997 & 0.00986 & -0.0271 & 0.0210 & -0.0305 & 0.0246 & -0.0407 & 0.0229 & -0.0359 \\
CAR8 & -0.0140 & 0.00557 & -0.0308 & 0.0169 & -0.0342 & 0.0217 & -0.0456 & 0.0302 & -0.0488 \\
SIZE & $20.607^{* * *}$ & $20.430^{* *}$ & $20.758^{* * *}$ & $20.714^{* *}$ & $20.538^{* * *}$ & $20.694^{*}$ & $20.531^{* * *}$ & $20.387^{* * *}$ & $20.778^{* * *}$ \\
EARNVOL & 1.734 & 1.387 & $2.0440^{*}$ & 1.484 & 1.898 & 1.600 & 1.855 & 1.438 & $1.98^{*}$ \\
INST & $0.872^{* * *}$ & $0.851^{* * *}$ & $0.890^{* * *}$ & $0.871^{* * *}$ & $0.873^{* * *}$ & $0.872^{* * *}$ & $0.871^{* * *}$ & $0.880^{* * *}$ & $0.865^{* * *}$ \\
BOARD & 0.325 & 0.345 & 0.308 & 0.304 & 0.339 & 0.290 & 0.357 & 0.328 & 0.323 \\
H & $0.506^{* * *}$ & $0.490^{* * *}$ & $0.521^{* * *}$ & $0.502^{* * *}$ & $0.509^{* * *}$ & $0.502^{* * *}$ & $0.509^{* * *}$ & $0.516^{* * *}$ & $0.498^{* * *}$ \\
Q & 1.196 & 1.207 & $1.187^{*}$ & 1.147 & $1.228^{*}$ & 1.219 & $1.177^{*}$ & 1.283 & 1.128 \\
\hline
\end{tabular}




\begin{tabular}{|c|c|c|c|c|c|c|c|c|c|}
\hline DIV & $0.0511^{* *}$ & $0.0763^{* * *}$ & $0.0417^{* *}$ & $0.0823^{* * *}$ & 0.0385 & $0.0781^{* * *}$ & $0.0435^{* *}$ & $0.0740^{* * *}$ & 0.0421 \\
\hline PRECAR & 0.00153 & 0.00821 & 0.0290 & 0.0229 & $-0.0325^{* * *}$ & 0.0177 & -0.0128 & 0.0199 & -0.0130 \\
\hline DEBT & $0.471^{* *}$ & $0.483^{* *}$ & $0.461^{* *}$ & $0.463^{* *}$ & $0.476^{* *}$ & $0.460^{* *}$ & $0.481^{* *}$ & $0.507^{* * *}$ & $0.443^{* *}$ \\
\hline
\end{tabular}

$*^{* * * * *}:$ significance levels at the $10 \%, 5 \%$ and $1 \%$, respectively

The results show that the mean abnormal returns before the announcement date "PRECAR" are, respectively, positive and negative for groups "P" and "N", but not statistically significant. This result may suggest that negative abnormal returns may increase due to firm's specific factors, particularly managerial and institutional ownership. Firms in the group "P" have average "PRECAR" values that are not significantly different from zero. In contrast, firms in groups " $\mathrm{N}$ " have small negative average value of "PRECAR" and statistically significant at the $1 \%$ for the group "N2". In fact, the sum of variables "PRECAR" and variables "CAR" is different for both groups, and is positive for the group "P" and negative for group " $\mathrm{N}$ ".

This result indicates that the negative response actions for the group " $\mathrm{N}$ " is not caused by the investor's anticipation of the firms' dividends distribution (due to the low negative value of the variable "PRECAR"). So we can conclude that economic factors affect investor's reaction after the distribution of dividends. In contrast, for groups "P1" and "N1", we has recorded in both cases two positive values of the sum of variables "PRECAR" and "CAR1" which are respectively equal to 0.0253 and 0.004 . This result indicates that the cumulative abnormal returns for the group "N1" are negative because the investor's anticipation of the act of dividends distribution by French firms.

The descriptive statistics for the subgroups are summarized as follows. Average variable size of for group "N" is higher than that for the group "P", except for "CAR6" and "CAR8". Moreover, the average earnings volatility for the group " $\mathrm{N}$ " is higher than that of the group "P". Institutional participation in the group "N" is slightly higher than in group "P" except for "CAR6" and "CAR8". Ownership concentration of group "N" is higher that of group "P" except for "CAR8". In contrast, firms with negative cumulative abnormal returns are characterized by higher growth opportunities for subgroups "N1" "N2" and "N6". Similarly, firms in the group "N" have higher leverage ratio than firms in the group, "P" except for "CAR1" and "CAR8".

\subsection{Result of the Event Study Method}

In order to assess the impact of dividends on shareholder wealth, the results of applying the method of event study are shown in Table 4.

Table 4. Effect of dividend on shareholder wealth in context of event study method

\begin{tabular}{cccc}
\hline séances & RAMt & T de Student & RAMCt \\
\hline-10 & 0,00001363 & 0,01054943 & 0.000013634 \\
-9 & 0,00015728 & 0,12169523 & 0,00017091 \\
-8 & 0,00063068 & 0,48798974 & 0,00080159 \\
-7 & 0,00053758 & 0,41595022 & 0,00133917 \\
-6 & 0,00022617 & 0,17500192 & 0,00186534 \\
-5 & 0,00030445 & 0,23556731 & 0,00281839 \\
-4 & 0,0009486 & 0,73398027 & 0,00074312 \\
-3 & $-\mathbf{0 , 0 0 2 0 7 5 2 7}$ & $-\mathbf{1 , 6 0 5 7 4 5 0 4}$ & 0,00153467 \\
-2 & 0,00079155 & 0,61246295 & 0,00029352 \\
-1 & $-0,00124115$ & $-0,96033929$ & 0,0012436 \\
0 & 0,00095008 & 0,73512804 & $-0,00131981$ \\
$\mathbf{1}$ & $\mathbf{- 0 , 0 0 2 5 6 3 4 1}$ & $\mathbf{- 1 , 9 8 3 4 4 6 1 3}$ & $-0,00441273$ \\
$\mathbf{2}$ & $\mathbf{- 0 , 0 0 3 0 9 2 9 2}$ & $\mathbf{- 2 , 3 9 3 1 5 7 5 6}$ & $-0,00454514$ \\
3 & $-0,00013241$ & $-0,10244957$ & $-0,00497651$ \\
4 & $-0,00043137$ & $-0,33377665$ & $-0,00635666$ \\
5 & $-0,00138015$ & $-1,06789317$ & $-0,0084396$ \\
$\mathbf{6}$ & $-\mathbf{0 , 0 0 2 0 8 2 9 3}$ & $\mathbf{- 1 , 6 1 1 6 7 5 3 9}$ & $-0,00971854$ \\
7 & $-0,00127894$ & $-0,98958515$ & $-0,01243109$ \\
$\mathbf{8}$ & $\mathbf{- 0 , 0 0 2 7 1 2 5 5}$ & $-\mathbf{2 , 0 9 8 8 3 9 7 7}$ & $-0,01414138$ \\
9 & $-0,00171029$ & $-1,32334387$ & $-0,01607834$ \\
10 & $-0,00193696$ & $-1,49872678$ &
\end{tabular}


Contrary to the empirical results of Dasilas and Leventis (2011), who conclude with positive and statistically significant abnormal returns at " $t=-1 "$ and " $t=-2 "$, the results of the event study method show that mean abnormal returns at " $t=-3 ", " t=1 ", " t=2 ", " t=6 "$ and $" t=8 "$ are negative and significant at levels $10 \%, 5 \%$, $5 \%, 10 \%$ and $5 \%$ respectively (validation of the hypothesis of investment opportunities). However, it should be noted that, unlike the findings of Asquith and Mullins (1983), Gurgul and al (2003), McClusky and al (2006), the market reaction at the announcement date is positive and not statistically significant.

Fluctuations of abnormal returns are significant before and after the announcement date (positive and negative reactions). This result is supported by Figure 3 below which shows how the French market positively and significantly reacts prior to the announcement date, $" t=-3$."

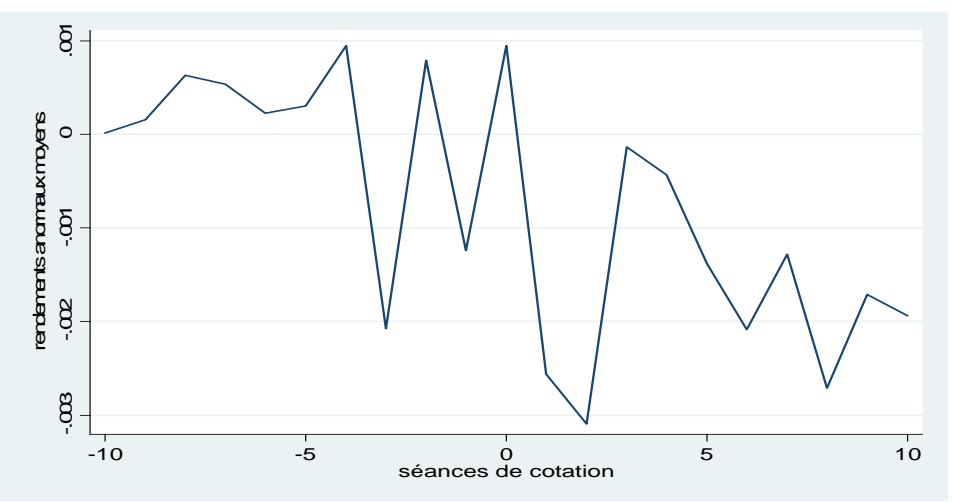

Figure 1. Stocks prices reaction to dividend distribution

The positive reaction of investors before the announcement date can be explained by speculative operations (sales and purchases of equities) to take advantage. However, despite the anticipation of the dividend distribution of the French market, the negative impact of dividends on shareholder wealth is not fully absorbed.

\subsection{Determinants of the Dividends' Information Content}

The results of the entire sample and those for the two sub-samples are reported in Table 5.

Table 5. Determinants of information content dividends

\begin{tabular}{|c|c|c|c|c|c|c|c|c|c|c|c|c|}
\hline \multirow[b]{2}{*}{ Variables } & \multicolumn{3}{|c|}{ CAR1 } & \multicolumn{3}{|c|}{ CAR2 } & \multicolumn{3}{|c|}{ CAR6 } & \multicolumn{3}{|c|}{ CAR8 } \\
\hline & Total 1 & P1 & N1 & Total 2 & P2 & N2 & Total 6 & P6 & N6 & Total 8 & P8 & N8 \\
\hline $\mathrm{C}$ & $0.0449^{*}$ & 0.0302 & 0.0422 & $0.0629^{*}$ & $0.0819^{* * *}$ & 0.0428 & 0.0148 & $0.116^{* * *}$ & 0.0211 & 0.0332 & 0.0630 & 0.0723 \\
\hline Inst & -0.0221 & -0.00653 & -0.0120 & -0.0239 & $-0.0528^{* * *}$ & -0.0195 & 0.0137 & $-0.0699^{* * *}$ & -0.00500 & 0.0219 & -0.0335 & -0.0195 \\
\hline Board & $-0.0206^{*}$ & 0.0126 & $-0.0405^{* * *}$ & $-0.0368^{* * *}$ & -0.0136 & $-0.0352^{* *}$ & $-0.0388^{* *}$ & $-0.0272^{*}$ & -0.0229 & -0.0277 & -0.0119 & $-0.0465^{*}$ \\
\hline $\mathrm{H}$ & -0.0312 & 0.00509 & -0.0154 & $-0.0446^{*}$ & -0.0286 & -0.0107 & -0.0645 & -0.0177 & 0.0145 & -0.0350 & 0.0127 & -0.0200 \\
\hline Size & -0.00013 & 0.000129 & -0.00149 & -0.00087 & 0.00125 & -0.00197 & -0.00038 & 0.000290 & -0.00227 & -0.00156 & 0.000829 & -0.0240 \\
\hline Earnvol & $-0.0043^{* *}$ & -0.00291 & 0.00234 & -0.00265 & -0.00115 & 0.00240 & -0.00218 & -0.00019 & -0.00060 & $-0.0084^{* *}$ & -0.00198 & -0.00298 \\
\hline Q & $-0.0070^{* *}$ & -0.00104 & -0.00231 & -0.00621 & -0.00155 & -0.00200 & 0.00169 & -0.00496 & -0.00492 & -0.00569 & -0.00238 & -0.0711 \\
\hline Div & $0.0299^{* * *}$ & -0.151 & -0.0486 & $0.0250^{*}$ & $-0.513^{* * *}$ & 0.0242 & $0.0319^{*}$ & $-0.473^{* * *}$ & 0.128 & 0.0257 & $-0.540^{* *}$ & -0.00105 \\
\hline Debt & 0.0102 & $-0.0660^{*}$ & 0.0295 & 0.0164 & 0.00488 & 0.0821 & $0.0143^{*}$ & 0.00468 & 0.212 & 0.0111 & -0.00321 & -0.0232 \\
\hline Cash & $0.0522^{* *}$ & $-0.0180^{*}$ & -0.00119 & $0.0590^{* *}$ & -0.0120 & 0.0158 & 0.0578 & -0.00061 & -0.00081 & 0.0383 & -0.0371 & 0.0210 \\
\hline Precar & $0.114^{* * *}$ & 0.0594 & $0.118^{* * *}$ & $0.202^{* * *}$ & 0.0158 & $0.159^{* * *}$ & $0.388^{* * *}$ & 0.00692 & $0.324^{* * *}$ & $0.534^{* * *}$ & 0.0707 & $0.481^{* * *}$ \\
\hline$R^{2}$ & $22.97 \%$ & $14.88 \%$ & $16.60 \%$ & $26.28 \%$ & $33.13 \%$ & $13.28 \%$ & $16.12 \%$ & $24.75 \%$ & $25.46 \%$ & $33.84 \%$ & $7.74 \%$ & $35.30 \%$ \\
\hline $\mathrm{F}$ & 3.309 & 1.927 & 2.310 & 3.957266 & 3.279 & 2.164 & 4.925 & 2.611 & 3.324 & 7.190 & 1.437 & 4.765 \\
\hline $\begin{array}{l}\text { Chow } \\
\text { Test }\end{array}$ & \multicolumn{3}{|c|}{$11.0134^{* * *}$} & $8.550^{* * *}$ & & & $6.891^{* * *}$ & & & $8.782^{* * *}$ & & \\
\hline
\end{tabular}

$\stackrel{* * * * * *}{*}$ : significance levels at the $10 \%, 5 \%$ and $1 \%$, respectively 
The results also show that the regressions explain between $16.12 \%$ and $33.84 \%$ of the variation in cumulative abnormal returns. Furthermore, the correlation coefficient varied between $7.74 \%$ and $33.13 \%$ of the variation in cumulative abnormal returns for the group "P" and between $13.28 \%$ and $35.30 \%$ for the group "N".

Earnings volatility: The coefficient of the variable "EARNVOL" is negative and significant at level of $5 \%$ for specifications "TOTAL1" and "TOTAL8". This result highlights the need to distribute more dividends in order to transmit information to outsiders.

Institutional ownership: The coefficient of institutional ownership is negative but not statistically significant for specifications "TOTAL1" and "TOTAL2". Similarly, for the sub samples, the institutional ownership negatively and significantly affects cumulative abnormal returns calculated on 2 and 6 days after the announcement date. This result means that institutional ownership does not play a disciplinary role to control managers' behavior, but rather, they follow a retrenchment behavior. In other words, institutional shareholders and dividends are two substitute mechanisms to control managers' behavior.

Ownership concentration: Ownership concentration measured by the Herfindahl index significantly and negatively cumulative abnormal returns. This result means that the distribution of capital in the hands of a few shareholders, directors and outside investors is not an effective tool of controlling managers' behavior (Kaplan and Minton, 1994).

Market anticipation: Contrary to what is expected, we recorded a positive relationship between market reaction and investors' anticipation. Similarly, for the sub groups, we recorded positive and statistically significant coefficients of the variable "PRECAR" for groups "N1" "N2", "N6" and "N8". This result means that the negative market reaction may be due to investors' anticipation of the act of distributing dividends.

Managerial ownership: The coefficient of the managerial ownership is negative and statistically significant in the case of specifications "TOTAL1", "TOTAL2" and "TOTAL6" at levels of 10\%, 1\% and 5\%, respectively. However, the coefficients of the variable "BOARD" are negative and statistically significant for the groups of firms "N1" "N2", "N8" and "P6". This result means that if managerial ownership for French firms is high, managers will behave at the expense of shareholders, which increases agency costs, and thus reduces shareholder wealth.

Tobin's Q: The coefficient of the variable "Q" Tobin is negative and statistically significant at level $1 \%$ for specification "TOTAL1". This result means that firms with future growth opportunities distribute fewer dividends than firms without growth opportunities.

Dividend yield: According to agency and signaling theories, and the empirical results of Wansley and al (1991), Lee and Yan (2003), Gurgul and al (2006) and Dasilas and Leventis (2011), dividend yield positively and significantly affects shareholder wealth for specifications "TOTAL1", "TOTAL2" and "TOTAL6" at levels of $1 \%, 10 \%$ and $10 \%$. This result reinforces the validity of our assumptions (1a) and (1b). However, for the two sub-samples, the coefficient of the variable dividend yield is negative and statistically significant for groups "P2", "P6" and "P8", which means that the dividend sends a signal of lack of growth opportunities.

Debt ratio: Consistent with the predictions of the signaling theory, the coefficient for the variable "DEBT" is positive and statistically significant at level of $10 \%$, which means that there are differences in dividend policy between firms that have different debt ratios. This result means that a high debt ratio promotes the distribution of dividends.

Liquidity ratio: we notice a positive and statistically significant coefficient of the variable liquidity for specifications "TOTAL1" and "TOTAL2" at levels of $1 \%$. This result means that firms with more liquidity distribute more dividends in order to attenuate the problem of overinvestment. For the sub-samples, liquidity significantly and negatively affects shareholder wealth, only for the group 'P1'.

\subsection{Results of the Chow Test}

To test the influence of economic factors on the cumulative abnormal returns after dividend distribution, we perform a Chow test (Zhenhu Jin, 2000), which is defined as follows:

$$
F_{c}=\frac{\left(E S S_{t}-E S S_{p}-E S S_{n}\right) / K}{\left(E S S_{p}+E S S_{n}\right) /(N-2 K)}
$$

With "ESS," the sum of the squares of the residuals obtained from the regression using the total sample, "ESSP" the sum of squares of the residuals obtained from the regression using firms with positive abnormal returns, 
"ESS $n$ " the sum of squared residuals obtained from the regression using firms with negative abnormal returns, "K": the number of regression coefficients, "N": number of observations of the total sample.

Chow test results are reported in Table 5 and are statistically significant at the $1 \%$. They reject the hypothesis 3 : the firm-specific factors affecting the reaction of stock prices following the distribution of dividends.

\subsection{Sensitivity Tests}

In this section, we examine sensitivity of our results to sector activity and the nonlinear relationship between managerial ownership and firm value.

\subsubsection{Impact of Activity Sectors on the Information Content of Dividends}

Michel (1979), Baker (1988) and Michael and Zhang (2008) discuss in their articles the impact of industries on the cumulative abnormal returns. Frankfurter and Wood (2002) insist that the systematic relationship between industry and dividend policy implies that managers are influenced by the actions of managers of competing firms in determining the level of the dividend ratio. Brav and al (2005) find that $38.3 \%$ of managers target a dividend yield ratio of other companies in the same industry. Tom and Walter (2011) examine, in the American context, the impact of industry on the dividend policy. To explore this possibility, we test the determinants of cumulative abnormal returns for 1, 2, 6 and 8 days after the announcement date for sub-samples related to industrial, trade and service sectors. The empirical results are presented in Table 6 and confirm the predictions of agency and signaling theories on the effect of dividend yield on shareholders' wealth.

Table 6. Effect of activity sectors on information content of dividends

\begin{tabular}{lccccccccccccc}
\hline \multicolumn{3}{c}{ Industrial sector } & \multicolumn{3}{c}{ Trade Sector } \\
\hline Variables & CAR1 & CAR2 & CAR 6 & CAR 8 & CAR1 & CAR2 & CAR6 & CAR8 & CAR1 & CAR2 & CAR6 & CAR8 \\
C & 0.0733 & 0.0768 & -0.00376 & 0.00426 & 0.00133 & 0.0634 & $0.121^{*}$ & 0.00372 & 0.0196 & -0.00486 & -0.0132 & 0.0184 \\
INST & $-0.0433^{* *}$ & $-0.077^{* * *}$ & -0.0213 & -0.0282 & 0.0222 & 0.0931 & -0.0205 & 0.00891 & 0.0307 & $0.0433^{*}$ & 0.0336 & 0.0577 \\
BOARD & $-0.0295^{*}$ & $-0.0325^{*}$ & -0.0227 & -0.0117 & -0.00956 & 0.0188 & -0.0358 & 0.00876 & -0.0231 & $-0.0554^{* *}$ & -0.0668 & $-0.0836^{*}$ \\
H & -0.0123 & 0.0400 & -0.0319 & -0.00807 & -0.0680 & $-0.181^{* * *}$ & $-0.238^{* * *}$ & -0.0185 & -0.0494 & -0.0298 & -0.0488 & -0.0309 \\
SIZE & 0.000481 & 0.000844 & 0.00273 & 0.00288 & -0.00102 & -0.00572 & 0.00348 & 0.00166 & -0.00202 & $-0.00342^{*}$ & -0.00224 & -0.00451 \\
EARNVOL & $-0.0079^{* * *}$ & -0.00202 & -0.00357 & -0.00662 & 0.00236 & 0.00244 & $-0.0289^{* *}$ & $-0.0260^{* *}$ & -0.000298 & -0.00914 & -0.0105 & $-0.00822^{*}$ \\
Q & $-0.0262^{* * * *}$ & $-0.0247^{* * *}$ & $-0.0281^{* * *}$ & $-0.0305^{* * *}$ & $0.0235^{* * *}$ & $0.0227^{* *}$ & 0.00691 & 0.0168 & -0.00114 & -0.00633 & -0.00201 & -0.00140 \\
DIV & -0.0521 & -0.00386 & 0.0724 & -0.00526 & $0.725^{* *}$ & $0.921^{*}$ & 0.198 & $-1.137^{*}$ & $0.0367^{* *}$ & $0.0663^{* * *}$ & $0.0563^{*}$ & $0.0689^{* *}$ \\
DEBT & 0.00189 & -0.0184 & 0.0140 & 0.0189 & $-0.0339^{*}$ & -0.0389 & -0.00175 & 0.00700 & 0.0252 & $0.117^{* * *}$ & $0.111^{*}$ & 0.0802 \\
CASH & 0.0894 & -0.0373 & 0.0819 & -0.0165 & 0.0458 & $0.293^{* *}$ & -0.0328 & 0.178 & $0.0997^{* * *}$ & $0.152^{* * *}$ & $0.147^{* *}$ & $0.166^{* *}$ \\
PRECAR & 0.0844 & $0.197^{* * *}$ & $0.179^{*}$ & $0.2968^{* * *}$ & 0.038 & $0.305^{* * *}$ & 0.152 & 0.175 & $0.162^{* * *}$ & $0.276^{* * *}$ & $0.579^{* * *}$ & $0.843^{* * *}$ \\
$R^{2}$ & $35.77 \%$ & $35.17 \%$ & $27.50 \%$ & $15.14 \%$ & $53.14 \%$ & $45.06 \%$ & $44.96 \%$ & $56.015 \%$ & $42.67 \%$ & $64.18 \%$ & $58.94 \%$ & $74.60 \%$ \\
F & 2.673 & 2.658 & 1.821 & 2.0527 & 2.587 & 2.148 & 2.143 & 2.910 & 2.786 & 5.300 & 4.444 & 8.344 \\
\hline
\end{tabular}

In doing so, we notice the positive effects of dividend yields for the trade sector for the specifications "CAR1" and "CAR2". These same results are recorded for the service sector. In contrast, for the trade sector for the specification "CAR8", dividends distribution negatively affects stock prices by sending a signal to investors about deterioration of growth opportunities. The coefficients on the institutional ownership are negative and statistically significant at the levels of $5 \%$ and $1 \%$ for specifications "CAR1" and "CAR2" respectively for the industrial sector. This result indicates that institutional ownership and dividends are two substitutable mechanisms to control managers' behavior of managers. However, contrary to the prediction of signaling theory, institutional ownership stimulates the distribution of dividends by insiders of firms belonging to service sector for the specification "CAR2". Firms belonging to the industrial, trade and service sectors with higher managerial ownership and a concentrated capital could distribute few dividends. This result holds true for specifications "CAR1" "CAR2" and "CAR6". Consistent with our assessment, the results of the specification "CAR2" for the service sector show that the smaller-sized firms distribute more dividends in order to transmit more information to the market. The increase in earnings volatility negatively affects shareholder wealth for the three sectors. Only 
for the industrial sector, does higher growth opportunities imply more need for liquidity, and therefore, few dividends paid, which will negatively affect shareholder wealth. However, for the trade sector, there was a reverse relationship for the specifications "CAR1" and "CAR2". The coefficients on leverage and liquidity ratio are positive and statistically significant for firms belonging to service sector. This result means that debt and dividends are two complementary mechanisms of signaling and that firms with more cash distribute more dividends to address the problem of overinvestment. Finally, the results show that outside investors expect the distribution of dividends by firms in industry and services and they react positively. In contrast, this relationship is valid only for specification "CAR2" for the trade sector.

\subsubsection{A Non-linear Relationship between Insider Ownership and Firm Valu}

Contrary to the results of Jensen and Meckling (1976), Morck and al (1988), Stulz (1988) argue that the relationship between managerial ownership cumulative abnormal returns is nonlinear. McConnell and Servaes (1990) confirm the existence of a non monotonic relationship between managerial ownership and shareholder wealth. At the low levels of managerial ownership, there is an alignment of interests between outsiders and managers with the increase of their share capital. However, for high levels of managerial ownership, there has been an entrenchment effect of shareholder wealth with the insiders' share capital. To illustrate this nonlinear effect, we define an interaction term that equals the product of the "DUMMY" variable and managerial ownership variable. The results are presented in table 7.

Table 7. Non-linear relationship between insider ownership and firm value

\begin{tabular}{lcccc}
\hline & CAR1 & CAR2 & CAR6 & CAR8 \\
\hline C & $0.0458^{*}$ & $0.0591^{*}$ & 0.0323 & 0.0356 \\
INST & -0.0205 & -0.0307 & -0.00769 & -0.00275 \\
BOARD & -0.0441 & 0.0663 & 0.160 & $0.244^{*}$ \\
BOARD*DUMMY & 0.0201 & -0.0883 & $-0.168^{*}$ & $-0.238^{*}$ \\
H & -0.0299 & $-0.0500^{*}$ & -0.0625 & -0.0242 \\
SIZE & -0.000175 & -0.000695 & -0.000418 & -0.00151 \\
EARNVOL & $-0.00435^{* *}$ & -0.00277 & -0.00435 & -0.00580 \\
Q & $-0.00705^{* *}$ & $-0.00640^{*}$ & -0.00486 & -0.00339 \\
DIV & $0.0298^{* * *}$ & $0.0251^{*}$ & 0.0255 & -0.221 \\
DEBT & 0.00987 & 0.01789 & 0.0101 & 0.000372 \\
CASH & $0.0532^{* *}$ & $0.0549^{* *}$ & 0.0351 & 0.00960 \\
PRECAR & $0.113^{* * *}$ & $0.2040^{* * *}$ & $0.382^{* * *}$ & $0.494^{* * *}$ \\
$R^{2}$ & $23.31 \%$ & $27.13 \%$ & $31.89 \%$ & $37.57 \%$ \\
F & 2.992 & 3.722 & 4.682 & 6.127 \\
\hline${ }^{* * * * * *}:$ significance levels at the $10 \%, 5 \%$ and $1 \%$, respectively & &
\end{tabular}

,${ }^{* * * * *}$ : significance levels at the $10 \%, 5 \%$ and $1 \%$, respectively

The results indicate that for high levels of managerial ownership, the coefficient of the "DUMMY * BOARD" variable is negative and statistically significant at level of $10 \%$ for "CAR6" and "CAR8". In contrast, for low levels of managerial ownership, the coefficient of the "BOARD" variable is positive and statistically significant for "CAR8". These results highlight the validity of the alignment and entrenchment hypotheses with increasing managerial ownership. The results of other control variables remain similar to the findings of the previous paragraph. The exception is related to "SIZE" and "DEBT" variables that become statistically insignificant.

\section{Conclusion}

The aim of this paper is to compare the results of the theoretical and empirical literature on the determinants of the reaction of stock prices following the distribution of dividends (Elisabete, 2011). Financial theory shows that dividends-distributing firms fall into two distinct categories; firms affected positively by the act of distribution and others negatively affected due to the specific characteristics of different firms (especially ownership structure and capital concentration). According to the hypothesis of deterioration of investment projects, the results point to a negative and statistically significant effect of dividends on shareholder wealth at day " $t=-3$ " before the announcement date and day " $t=1 ", " t=2 ", " t=6$ "and " $t=8$ "after the announcement date. However, we concluded that the French market anticipates the distribution of dividends and responds positively. By using the "Chow" test, the results show that firms' characteristics of firms significantly affect dividends' informational effect. 


\section{References}

Agrawal, A., \& Jayaraman, N. (1994). The dividend policies of all-equity firms: a direct test of the free cash flow theory. Managerial Decision Economics, 15, 139-148. http://dx.doi.org/10.1002/mde.4090150206

Alpa Dhanani. (2005). Corporate Dividend Policy: The Views of British Financial Managers. Journal of Business Finance and Accounting, 32(7). http://dx.doi.org/10.1111/j.0306-686X.2005.00643.x

Ambarish. A., K. John \& J. Williams. (1987). Efficient Signalling with Dividends and Investment. Journal of Finance, 42, 321-44.

Amidu, M., \& Abor, J. (2006). Determinants of dividend payout ratios in Ghana. The Journal of Risk Finance, 7(2), 136-145. http://dx.doi.org/10.1108/15265940610648580

Ang. J., \& Cole. J., Lin. (2000). Agency Costs and Ownership Structure. The Journal of Finance, 55(1), 81-106.

Ariff, M., \& Finn, F. (1986). Announcement effects and market efficiency in a thin market: an empirical application to the Singapore equity market. Asia Pacific Journal of Management, 6, 243-267. http://dx.doi.org/10.1007/BF01733767

Asquith. P., \& DW Mullins. (1986). Signalling With Dividends, Stock Repurchases And Equity Issues. Financial Management, 27. http://dx.doi.org/10.2307/3664842

Baker H. K. (1988). The Relationship Between Industry Classification and Dividend Policy. Southern Business Review, 1-8.

Baker, H. K., Farrelly, G. E., \& Edelman, R. B. (1985). A survey of management views on dividend policy. Financial Management, 22, 78-84. http://dx.doi.org/10.2307/3665062

Baker Powell et Veit. (2002). Revisiting The Dividend Puzzle Do All Of The Pieces Now Fit? Review of Financial Economics, 11, 241- 261. http://dx.doi.org/10.1016/S1058-3300(02)00044-7

Baker Powell. (1999). How Corporate Managers View Dividend Policy. Quarterly Journal of Business and Economics, 38(2).

Ball, R., Kothari, S. P., \& Robin, A. (2000). The effect of international institutional factors on properties of accounting earnings. Journal of Accounting and Economics, 29, 1-51. http://dx.doi.org/10.1016/S0165-4101(00)00012-4

Barney, D., \& Schooley, K. L. (1994). Using Dividend Policy and Managerial Ownership to Reduce Agency Costs. Journal of Financial Research, 17(3), 363-373.

Beiner, N., \& Gibson, R. (1999). A theoretical analysis of the liquidity risk premium embedded in the prices of voting and nonvoting stocks. Journal of Corporate Finance, 5, 209-225. http://dx.doi.org/10.1016/S0929-1199(99)00006-1

Belden, S., Todd, F., \& Knapp, B. (2005). Dividends and directors: do outsiders reduce agency costs? Business and Society Review, 110, 171. http://dx.doi.org/10.1111/j.0045-3609.2005.00009.x

Bessler, W., Drobetz, W., \& Seim, M. (2009). Motives and valuation effects of share repurchase announcements in Germany: comparison of established firms and initial public offerings. Justus Liebig University.

Bhattacharay, S. (1979). Imperfect information, dividend policy, and the bird in the hand fallacy. Bell Journal of Economics, 10(1), 259-270. http://dx.doi.org/10.2307/3003330

Binder, J. J. (1998). The Event Study Methodology Since 1969. Review of Quantitative Finance and Accounting, 11, 111-137. http://dx.doi.org/10.1023/A:1008295500105

Boehem, R., \& Sorescu, D. (2002). The long run performance following dividend initiations and resumptions: underreaction or product of chance? Journal of Finance, 57, 871-900. http://dx.doi.org/10.1111/1540-6261.00445

Brav, A., Graham, J., Harvey, C., \& Michaely, R. (2005). Payout policy in the $21^{\text {st }}$ century. Journal of Financial Economics, 77, 483-527. http://dx.doi.org/10.1016/j.jfineco.2004.07.004

Brown, D., \& Higgins, H. (2005). Managers' guidance of analysts: international evidence. Journal of Accounting and Public Policy, 24, 280-299. http://dx.doi.org/10.1016/j.jaccpubpol.2005.05.001

Brown, S. J., \& Warner, J. B. (1985). Using Daily Returns: The Case of Event Studies. Journal of Financial Economics, 14, 3-31. http://dx.doi.org/10.1016/0304-405X(85)90042-X 
Chen, C., \& Steiner, L. (1999). Managerial Ownership and Agency Conflicts: a Nonlinear Simultaneous Equation Analysis of Managerial Ownership, Risk Taking, Debt Policy, and Dividend Policy. The Financial Review, 34, 119-136. http://dx.doi.org/10.1111/j.1540-6288.1999.tb00448.x

Chen, C. R., Guo, W., \& Mande, V. (2003). Managerial ownership and firm valuation: evidence from Japanese firms. Pasific Basin Finance Journal, 11, 267-283. http://dx.doi.org/10.1016/S0927-538X(03)00024-6

Chen, L. (2009). On the reversal of return and dividend growth predictability: a tale of two periods. Journal of Financial Economics, 92, 128-151. http://dx.doi.org/10.1016/j.jfineco.2008.04.004

Cheng, T., Wallace, N., \& Leung, T. (2011). Insider trading returns and dividend signals. International Review of Economics and Finance, 20, 421-429. http://dx.doi.org/10.1016/j.iref.2010.11.016 PMid:16735669

Darling Paul, G. (1957). The influence of expectations and liquidityon dividend policy. Journal of Political Economy, 65, 209-224.

Dasilas, A., \& Leventis, S. (2011). Stock market reaction to dividend announcements: Evidence from the Greek stock market. International Review of Economics and Finance, 20, 302-311. http://dx.doi.org/10.1016/j.iref.2010.06.003. PMid:16735669

David, J., \& Osobov, I. (2008). Why do firms pay dividends? International evidence on the determinants of $\begin{array}{lllll}\text { dividend policy. Journal of Financial Economics, } & \text { 89, }\end{array}$ http://dx.doi.org/10.1016/j.jfineco.2007.06.006

Deangelo, H., \& Deangelo, L. (2006). The Irrelevance of the MM Dividend Irrelevance Theorem. Journal of Financial Economics, 79, 293-315. http://dx.doi.org/10.1016/j.jfineco.2005.03.003

DeFond, M., Hung, M., \& Trevant, R. (2004). Investor protection and the information content of annual earnings announcements: International evidence. Unpublished working Paper, University of Washington, Seattle, WA.

Demirguc, A, Kunt, V., \& Maksimovic. (1998). Law, finance and firm growth. Journal of Finance, 53, 2107-2137.

Demsetz, H., \& Lehn, K. (1985). The Structure of Corporate Ownership: Causes and Consequences. Journal of Political Economy, 93(6), 1155-1177. http://dx.doi.org/10.1086/261354

Dewenter, K., \& Warther, V. (1998). Dividends, asymmetric information, and agency conflicts: Evidence from a comparison of the dividend policies of Japanese and U.S. firms. Journal of Finance, 53, 879-904. http://dx.doi.org/10.1111/0022-1082.00038

Dickens, Casey \& Newman. (2003). Bank Dividend Policy: Explanatory Factors. Quarterly Journal of Business and Economics, 41(2).

Dyl, E., \& Weigand, R. (1998). The information content of dividend initiations: additional evidence. Financial Management, 27, 27-35. http://dx.doi.org/10.2307/3666272

Easstons, S. A., \& Sinclair. (1989). The impact of unexpected earnings and dividends on abnormal returns to equity. Accounting and Finance, 29, 1-19.

Easterbrook, F. H. (1984). Two Agency Cost Explanations of Dividends. The American Economic Review, 74(4), 250-259.

Elisabete, S. (2011). Investor sentiment and the market reaction to dividend news: European evidence. Managerial Finance, 37, 1213-1245. http://dx.doi.org/10.1108/03074351111175100

Faccio M. et Lang. (2002). The ultimate ownership of Western European corporations. Journal of Financial Economics, 65, 365-395. http://dx.doi.org/10.1016/S0304-405X(02)00146-0

Faccio, M., Lang, L. H. P., \& Young, L. (2001). Dividends and expropriation. American Economic Review, 91, 54-78. http://dx.doi.org/10.1257/aer.91.1.54

Fama, E. F., \& French, K. R. (1988). Dividend yields and expected stock returns. Journal of Financial Economics, 22, 3-25. http://dx.doi.org/10.1016/0304-405X(88)90020-7

Fama, E., \& French, K. (2001). Disappearing dividends: Changing firm characteristics or lower propensity to pay? Journal of Financial Economics, 60, 3-43. http://dx.doi.org/10.1016/S0304-405X(01)00038-1

Fama, E., \& French, K. (1993). Common risk factors in the returns on stocks and bonds. Journal of Financial Economics, 33(1), 3-56 
Frankfurter, G. M., \& Wood, B. G. (2002). Dividend policy theories and their empirical tests. International Review of Financial Analysis, 11, 111-138. http://dx.doi.org/10.1016/S1057-5219(02)00071-6

Fuller, K. (2003). The impact of informed trading on dividend signalling: a theoretical and empirical examination. Journal of Corporate Finance, 3, 385-407. http://dx.doi.org/10.1016/S0929-1199(02)00052-4

Garrett, I., \& Priestley, R. (2000). Dividend behavior and dividend signalling. Journal of Financial and Quantitative Analysis, 35, 173-189. http://dx.doi.org/10.2307/2676189

Gelb, D. (2000). Managerial ownership and accounting disclosures: an empirical study. Review of Quantitative Finance and Accounting, 15(2), 169-185. http://dx.doi.org/10.1023/A:1008321230900

Gordon \& Shapiro. (1956). Capital Equipment Analysis: The Required Rate of Profit. Management Science, 3(1), 102. http://dx.doi.org/10.1287/mnsc.3.1.102

Gordon, M. J. (1959). Dividends, earnings, and stock prices. Review of Economics and Statistics, 41(2), 99-105. http://dx.doi.org/10.2307/1927792

Grullon, G., Michaely, R., \& Swaminathan, B. (2002). Are dividend changes a sign of firm maturity. Journal of Business, 75(3). http://dx.doi.org/10.1086/339889

Gurgul, H., Mestel, R., \& Schleicher, C. (2003). Stock market reactions to dividend announcements: Empirical evidence from the Austrian stock market. Financial Markets and Portfolio Management, 17, 332-350. http://dx.doi.org/10.1007/s11408-003-0304-1

Gurgul Henryk, Majdosz Pawel \& Mestel Roland. (2006). Implications of Dividend Announcements for Stock Prices and Trading Volume of DAX Companies. Finance a Uver? Czech Journal of Economics and Finance, 56(1), 58-68.

Hamid, U. M. (2003). Effect of dividend announcement on shareholder's value: evidence from Dhaka stock exchange. The International Review of Finance, in Press.

Handjinicolaou, G., \& Kalay. (1984). Wealth Redistributions Of Changes In Firm Value: an Analysis of Returns To Bondholders And Stockholders Around Dividend Annoucements. Journal Of Financial Economics, 13, $35-63$.

Healy, P. M., \& Palepu, K. G. (1988). Earnings information conveyed by dividend initiations and omissions. Journal of Financial Economics, 21, 149-175. http://dx.doi.org/10.1016/0304-405X(88)90059-1

Hermalin, B., \& Weisbach, M. (1991). The effects of board composition and direct incentives on firm performance. Financial Management, 20(4). http://dx.doi.org/10.2307/3665716

Hiraki, T., Inoue, H., \& Ito, A. (2003). Corporate governance and firm value in Japan: evidence from 1985 to 1998. Pasific Basin Finance Journal, 11, 239-265. http://dx.doi.org/10.1016/S0927-538X(03)00023-4

Holder, M. E., Langrehr, F. W., \& Hexter, J. L. (1998). Dividend policy determinants: an investigation of the influences of stakeholder theory. Financial Management, 27, 73-82. http://dx.doi.org/10.2307/3666276

Impson, M. (1997). Market Reaction To Dividend-Decrease Announcement: Public Utilities Vs. Unregulated Industrial Firms. Journal of Financial Research, 20, 407-422.

Jacelly \& Maximilaiano. (2010). Ownership and Capital Structure in Latin America. Journal of Business Research, 63, 248-254. http://dx.doi.org/10.1016/j.jbusres.2009.03.010

Janice, C., Kian, N., \& Peter, V. (2011). Dividend initiations and long run IPO performance. Australian Journal of Management, 36, 267. http://dx.doi.org/10.1177/0312896211405569

Jarell, G., \& Poulsen, A. (1988). Dual class recapitalization as anti takeover mechanisms: the recent evidence. Journal of Financial Economics, 20, 129-152. http://dx.doi.org/10.1016/0304-405X(88)90042-6

Jensen \& Meckling. (1976). Theory of the Firm: Managerial Behaviour, Agency Costs and Ownership Structure. Journal of Financial Economics, 3(4).

Jensen, M. C. (1986). Agency Costs of Free Cash Flow, Corporate Finance and Takeovers. The American Economic Review, 76(2), 323-329.

John, K., \& Williams, J. (1985). Dividends, dilution, and taxes: a signalling equilibrium. Journal of Finance, 40, 1053-1070.

Kalay, A. (1980). Signaling, information content, and the reluctance to cut dividends. Journal of Financial and Quantitative Analysis, 15, 855-869. http://dx.doi.org/10.2307/2330564 
Kamstra, M. (2000). Fundamental Valuation of Zero Dividend Firms. WP, Department of Economics, Canada.

Kaplan, S. N., \& B. A. Minton. (1994). Appointment of Outsiders to Japanese Boards: Determinants and Implications for managers. Journal of Financial Economics, 36, 225-258. http://dx.doi.org/10.1016/0304-405X(94)90025-6.

Kimie, H., \& Pascal, N. (2011). Ownership concentration and dividend policy in Japan. Managerial Finance, 37(4).

Knopf, J., \& Teall, J. (1996). Risk taking behaviour in the US thrift industry: ownership structure and regulatory changes. Journal of Banking and Finance, 20, 1329-1350. http://dx.doi.org/10.1016/0378-4266(96)00010-6

Koch, A. S., \& Sun, A. X. (2004). Dividend changes and the persistence of past earnings changes. Journal of Finance, 59(5). http://dx.doi.org/10.1111/j.1540-6261.2004.00693.x

Konstantinos, B., Nikolopoulos, K., \& Ramgandhi, G. (2011). Dividend signalling under economic adversity: Evidence from the London Stock Exchange. International Review of Financial Analysis, 20, 364-374. http://dx.doi.org/10.1016/j.irfa.2011.07.003

La Porta, F., \& Lopez-de-Silanes, A. Shleifer. (1990). Corporate ownership around the world. Journal of Finance, 54, 471-517. http://dx.doi.org/10.1111/0022-1082.00115

La Porta, R., Lopez-De-Silanes, F., \& Shleifer, A. Vishny. (2000). Tunnelling. American Economic Review, Papers and Proceedings, 90, 22-27. http://dx.doi.org/10.1257/aer.90.2.22

Lang, H. P., \& Litzenberger, R. (1989). Dividend Announcements: Cash Flow Signalling VS Free Cash Flow $\begin{array}{llll}\text { Hypothesis. Journal of } & \text { Financial }\end{array}$ http://dx.doi.org/10.1016/0304-405X(89)90077-9

Lee, B. S., \& Yan, N. A. (2003). The market's differential reactions to forward-looking and backward-looking dividend changes. Journal of Financial Research, 26, 449-468. http://dx.doi.org/10.1111/1475-6803.00068

Lee Bong, S. (1995). The response of stock prices to permanent and temporary shocks to dividends. Journal of Financial and Quantitative Analysis, 30, 1-22.

Leland, H., \& Pyle, D. (1977). Information Asymmetrics, Financial Structure, and Financial Intermediation. Journal of Finance, 32, 371-388. http://dx.doi.org/10.2307/2326770

Liang, H., Moreau, B., \& Jung, C. (2011). Investment opportunities and dividend omissions. Journal of Business Research, 64, 1108-1115. http://dx.doi.org/10.1016/j.jbusres.2010.11.012

Lie, E. (2000). Excess Funds and Agency Problems: An Empirical Study of Incremental Cash Disbursements. The Review of Financial Studies, 13(1), 219-247.

Lightner, Robert \& Wilkinson. (2008). Dividend Taxes and Security Prices: The Reaction Of Dividend-Paying Stocks To The Jobs And Growth Tax Relief Reconciliation Act Of 2003. Advances in Taxaxtion, 18, 53-72. http://dx.doi.org/10.1016/S1058-7497(08)18003-6

Lintner, J. (1956). Distribution of Incomes of Corporations among Dividends, Retained Earnings and Taxes. The American Economic Review, 46(2), 97-113.

Litzenberger, R., \& Ramaswamy, K. (1979). The effects of personal taxes and dividends on capital asset prices: theory and empirical evidence. Journal of Financial Economics, 7, 163-195. http://dx.doi.org/10.1016/0304-405X(79)90012-6

Margaret Johnston. (2007). A Review of the Application of Event Studies In Marketing. Academy of Marketing Science Review, 4.

McClusky, T., Burton, B. M., Power, D. M., \& Sinclair, C. D. (2006). Evidence on the Irish stock market's reaction to dividend announcements. Applied Financial Economics, 16, 617-628. http://dx.doi.org/10.1080/09603100600639058

McConnell, J., \& Servaes, H. (1990). Additional evidence on equity ownership and corporate value. Journal of Financial Economics, 27(2). http://dx.doi.org/10.1016/0304-405X(90)90069-C

McWilliams, V. B. (1990). Managerial share ownership and the stock price effects of antitakeover amendment proposals. Journal of Finance, 1627-1640.

Megginson, W. L. (1990). Restricted voting stock, acquisition premiums, and the market value of corporate control. The Financial Review, 25, 175-198. http://dx.doi.org/10.1111/j.1540-6288.1990.tb00791.x 
Michael \& Zhang. (2008). Dividend Initiations By High-Tech Firms, 11, 2001.

Michaely, R., Benartzi, S., \& Thaler, R. (1997). Do changes in dividends signal the future or the past? Journal of Finance, 52, 1007-1034.

Michel, A. (1979). Industry influence on dividend policy. Financial Management, 22-26.

Miguel, D. A., \& Pindado, J. (2001). Determinants of Capital Structure: New Evidence From Spanish Panel Data. Journal of Corporate Finance, 7, 77-99. http://dx.doi.org/10.1016/S0929-1199(00)00020-1

Miler, M., \& Modigliani, F. (1961). Dividend Policy, Growth and Valuation Shares. Journal of Business, 34, 411-433. http://dx.doi.org/10.1086/294442

Miller, M., \& Rock, K. (1985). Dividend Policy under Asymmetric Information. The Journal Of Finance, 40(4), 1031-1051.

Morck, R., A. Shleifer \& R. W. Vishny. (1988). Management Ownership and Market Valuation: an Empirical Analysis. Journal of Financial Economics, 20, 293-315. http://dx.doi.org/10.1016/0304-405X(88)90048-7

Mougoué, M., \& Rao, R. (2003). The Information Signalling Hypothesis of Dividends: Evidence from Cointegration and Causality Tests. Journal of Business Finance and Accounting, 30(3), 441-478. http://dx.doi.org/10.1111/1468-5957.t01-1-00004

Neil Fargher \& Robert Weigand. (2009). Cross-Sectional Differences In The Profits, Returns And Risk of Firms Initiating Dividends. Managerial Finance, 35, 509. http://dx.doi.org/10.1108/03074350910956972

Nissim, D., \& Ziv, A. (2001). Dividend changes and future profitability. Journal of Finance, 56, 2111-2133. http://dx.doi.org/10.1111/0022-1082.00400

Oliver Zhen. (2007). Taxes and valuation: evidence from dividend change announcements. The Journal of the American Taxation Association, 29, 1. http://dx.doi.org/10.2308/jata.2007.29.2.1

Omran, M., \& Pointon, J. (2004). Dividend policy, trading characteristics and share prices: empirical evidence from Egyptian firms. International Journal of Theoretical and Applied Finance, 7(2), 121-133. http://dx.doi.org/10.1142/S0219024904002384

Ooi, J. T. (2001). Dividend policy characteristics of U.K. property companies. Journal of Real Estate Portfolio Management, 7(2), 133-142.

Philip, B., Janice, C., \& Verhoeven, P. (2008). The accuracy of analysts' dividend forecasts around the world. Pacific-Basin Finance Journal, 16, 416-435.

Ross, S. (1977). The Determination of Financial Structure: The Incentive Signalling Approach. Bell Journal of Economics, 8, 23-40. http://dx.doi.org/10.2307/3003485

Rozeff, M. (1982). Growth, Beta and Agency Costs as Determinants of Dividend Payout Ratios. The Journal of Financial Research, 5(3).

Rubin, A., \& Smith, D. (2009). Institutional ownership, volatility and dividends. Journal of Banking and Finance, 33, 627-639. http://dx.doi.org/10.1016/j.jbankfin.2008.11.008

Rubinstein, M. (1976). The Valuation of Uncertain Income Streams and Pricing of Options. Bell Journal of Economics, 2, 407-425. http://dx.doi.org/10.2307/3003264

Samuel, K., \& Edward, M. (2011). Dividend Policy and Bank Performance in Ghana. International Journal of Economics and Finance, 3(4).

Shania, T., \& Yuce, A. (2011). Information content of dividend announcements: an investigation of the Indian stock market. The International Business and Economics Research Journal, 10(5).

Shleifer, A., \& Vishny, R. (1997). A survey of corporate governance. Journal of Finance, 52(2), 737-783.

Shleifer, A., \& Vishny, R. (1986). Large Shareholders and Corporate Control. Journal of Political Economy, 94(3), 461-488. http://dx.doi.org/10.1086/261385

Slovin, M., Sushka, M., \& Polonchek, J. (1993). The value of bank durability: borrowers as bank stakeholders. Journal of Finance, 48, 247-266.

Stulz, R. (1988). Managerial Control of Voting Rights: Financing Policies and The Market For Corporate Control. Journal of Financial Economics, 20(1), 25-54. http://dx.doi.org/10.1016/0304-405X(88)90039-6 
Thompson, R. (1985). Conditioning the return generating process on firm specific events: a discussion of event studies methods. Journal of Financial and Quantitative Analysis, 20(2). http://dx.doi.org/10.2307/2330952

Tom, V., \& Walter, A. (2011). Intra-industry conformity in dividend policy. Managerial Finance, 37(6).

Viswanath, Kyungkim \& Pandit (2002). Dilution, Dividend Commitments And Liquidity: Do Dividend Changes Reflect Information Signalling? Review of Quantitative Finance and Accounting, 18, 359-379. http://dx.doi.org/10.1023/A:1015453703511

Wang, K., Erickson, J., \& Gau, G.W. (1993). Dividend policies and dividend announcement effects for real estate investment trusts. Journal of the American Real Estate and Urban Economics Association, 21(2), 185-201. http://dx.doi.org/10.1111/1540-6229.00607

Wansley, J., Sirmans, C., Shilling, J., \& Lee, Y. (1991). Dividend change announcement effects and earnings volatility and timing. Journal of Financial Research, 14, 37-49.

Zeng, T. (2003). What determines dividend policy: a comprehensive test? Journal of American Academy of Business, 2(2), 304-309.

Zhenhu Jin. (2000). On the Differential Market Reaction to Dividend Initiations. The Quarterly Review of Economics and Finance, 40, 263-277. http://dx.doi.org/10.1016/S1062-9769(99)00052-6

Zingales, L. (1995). What determines the value of corporate votes? The Quarterly Journal of Economics, 110, 1047-1073. 